\title{
PERAN ADVOKAT DALAM MEMBERIKAN BANTUAN HUKUM KEPADA MASYARAKAT DALAM PERSPEKTIF HAK ASASI MANUSIA
}

\author{
Herning Setyowati \\ Mahasiswa Fakultas Hukum, Universitas \\ Negeri Semarang \\ Surel: herning987@students.unnes.ac.id
}

\author{
Nurul Muchiningtias \\ Mahasiswa Fakultas Hukum, Universitas \\ Negeri Semarang \\ Surel: muchiningt@gmail.com
}

\begin{abstract}
ABSTRAK
Bantuan hukum memiliki kedudukan yang cukup penting dalam setiap sistem peradilan pidana, perdata, dan tata usaha negara tidak terkecuali di Negara Indonesia. Konsep bantuan hukum berkaitan dengan hak-hak seseorang guna menjalankan hak-hak tersebut, oleh karenanya bantuan hukum dijalankan oleh para ahli hukum dan orang-orang yang berpengalaman dalam rangka untuk menjalankan profesinya. Bantuan hukum dijalankan oleh pemberi bantuan hukum yang berorientasi pada nilai-nilai kemulian, yaitu aspek kemanusiaan untuk memperjuangkan hak-hak manusia untuk hidup sejahtera dan berkeadilan.
\end{abstract}

\section{RIWAYAT ARTIKEL}

Article History

Diterima 15 Maret 2017

Dipublikasi 20 November 2018

\section{KATA KUNCI}

Keywords

Advokat, Bantuan Hukum, Hak Asasi Manusia

\section{HOW TO CITE (saran perujukan):}

Setyowati, H. \& Muchiningtias, N. (2018). "Peran Advokat dalam Memberikan Bantuan Hukum kepada Masyarakat Perspektif Hak Asasi Manusia", Lex Scientia Law Review. Volume 2 No. 2, November, hlm. 155-168 


\section{PENDAHULUAN}

Pasal 1 angka 1 Bab I Undang-Undang Nomor 16 Tahun 2011 tentang Bantuan Hukum, menyebutkan: "Bantuan Hukum adalah jasa hukum yang diberikan oleh Pemberi Bantuan Hukum secara cuma-cuma kepada Penerima Bantuan Hukum". Sedangkan penerima bantuan hukum di sini adalah orang atau kelompok orang miskin. dan Pemberi Bantuan Hukum adalah Lembaga Bantuan Hukum atau organisasi kemasyarakatan yang memberi layanan bantuan hukum seperti yang dijelaskan dalam Undang-Undang Nomor 16 Tahun 2011 tentang Bantuan Hukum. Menurut Undang-Undang Nomor 18 Tahun 2003 Pasal 1 angka 9, Bab I memberi pengertian bahwa "Bantuan Hukum adalah jasa hukum yang diberikan oleh Advokat secara cuma-cuma kepada Klien yang tidak mampu".

Bantuan hukum memiliki kedudukan yang cukup penting dalam setiap sistem peradilan pidana, perdata, dan tata usaha negara tidak terkecuali di Negara Indonesia. Secara umum dapat dikatakan bahwa bantuan hukum mempunyai tujuan yang terarah pada bermacam-macam kategori sosial di dalam masyarakat, yaitu: (1) Menjamin dan memenuhi hak bagi Penerima Bantuan Hukum untuk mendapatkan akses keadilan; (2) Mewujudkan hak konstitusional segala warga negara sesuai dengan prinsip persamaan kedudukan di dalam hukum; (3) Menjamin kepastian penyelenggaraan Bantuan Hukum dilaksanakan secara merata di seluruh wilayah Negara Republik Indonesia; dan (4) Mewujudkan peradilan yang efektif, efisien, dan dapat dipertanggungjawabkan.

Konsep bantuan hukum berkaitan dengan hak-hak seseorang guna menjalankan hak-hak tersebut, oleh karenanya bantuan hukum dijalankan oleh para ahli hukum dan orang-orang yang berpengalaman dalam rangka untuk menjalankan profesinya. Bantuan hukum dijalankan oleh pemberi bantuan hukum yang berorientasi pada nilai-nilai kemulian, yaitu aspek kemanusiaan untuk memperjuangkan hak-hak manusia untuk hidup sejahtera dan berkeadilan.

Pemberian bantuan hukum tersebut dapat diberikan kepada semua orang tanpa membedakan status sosial seseorang. Hal tersebut adalah sebagaimana yang ada pada negara hukum (rechtsstaat) di mana negara mengakui dan melindungi hak asasi manusia setiap individu. Pengakuan negara terhadap hak individu ini tersirat di dalam persamaan kedudukan di hadapan hukum bagi semua orang. Pasal $28 \mathrm{D}$ ayat (1) Undang-Undang Dasar 1945 berbunyi, "Setiap orang berhak atas pengakuan, jaminan, perlindungan, dan kepastian hukum yang adil serta perlakuan yang sama di hadapan hukum". Oleh karenanya, setiap individu dijamin oleh undang-undang untuk memperoleh bantuan hukum.

Selain Advokat, pemberian bantuan hukum di masyarakat dapat diberikan oleh Paralegal, Dosen Fakultas Hukum, dan Mahasiswa Fakultas Hukum yang dianggap mengerti tentang hukum dan memiliki kemampuan serta pengalaman di 
bidang hukum. Namun, dalam penulisan makalah ini lebih berfokus kepada Advokat sebagai pemberi bantuan hukum kepada masyarakat.

\section{Rumusan Masalah}

1. Bagaimana penggunaan jasa Advokat di Indonesia sebagai salah satu bentuk bantuan hukum?

2. Bagaimana sudut pandang hak asasi manusia menilai bantuan hukum yang diberikan oleh Advokat?

\section{Metode Penulisan}

Penelitian menggunakan pendekatan deskriptif kualitatif dan jenis penelitian yang digunakan adalah kepustakaaan/library research yaitu pengumpulan data atau karya tulis ilmiah yag bertujuan dengan obyek penelitian atau pengumpulan data yang bersifat kepustakaan, atau telaah yang dilaksanakan untuk memecahkan suatu masalah yang pada dasarnya bertumpu pada penelaah kritis dan mendalam terhadap bahan-bahan pustaka yang relevan.

\section{PEMBAHASAN}

\section{A. Penggunaan Jasa Advokat Di Indonesia Sebagai Salah Satu Bentuk Bantuan Hukum}

Pelaksanaan hukum di dalam masyarakat sangatlah bergantung pada kesadaran hukum suatu masyarakat dikarenakan manusia adalah subjek hukum. Namun selain tergantung pada kesadaran hukum masyarakat juga tergantung dan sangat ditentukan oleh pelaksanaan penegakan hukum oleh para petugas penegak hukum. Oleh karenanya banyak peraturan hukum yang tidak dapat terlaksana dengan baik dikarenakan oknum penegak hukum kurang paham dalam melaksanakan tugas dan tanggung jawabnya (Abdurrahman, 1980:14).

Pemberian bantuan (pembelaan) hukum bagi masyarakat tidak mampu hanya dapat dilakukan oleh Advokat yang sudah terdaftar pada Pengadilan Tinggi setempat. Pemberian bantuan hukum tersebut dapat dilakukan melalui : Bantuan (pembelaan) hukum yang dilakukan oleh Advokat secara perorangan Bantuan (pembelaan) hukum yang dilakukan oleh Advokat secara kelembagaan melalui Lembaga Bantuan Hukum setempat.

Advokat adalah orang yang berprofesi memberi jasa hukum, baik di dalam maupun di luar pengadilan yang memenuhi persyaratan berdasarkan ketentuan Undang-Undang Nomor 18 Tahun 2003 tentang Advokat. Jasa yang diberikan Advokat berupa memberikan konsultasi hukum, bantuan hukum, menjalankan kuasa, mewakili, mendampingi, membela, dan melakukan tindakan hukum lain untuk kepentingan hukum klien (jasa hukum). Advokat adalah pengacara yang diangkat oleh Menteri Kehakiman setelah mendapat nasihat dari Mahkamah 
Agung. Batas wilayah hukum tugas dari seorang advokat adalah seluruh propinsi di Indonesia.

Dasar dari pemberian bantuan hukum bagi masyarakat tidak mampu dilakukan berdasarkan ketentuan-ketentuan:

1) Undang-Undang Nomor 4 Tahun 2004 tentang Kekuasaan Kehakiman;

2) Pasal 13 (1) tentang : Organisasi , administrasi , dan finansial Mahkamah Agung dan badan peradilan yang berada di bawah kekuasaan Mahkamah Agung.

3) Pasal 37 tentang : Setiap orang yang tersangkut perkara berhak memperloleh bantuan hukum.

4) Undang-Undang Nomor 8 Tahun 1981 tentang Kitab Undang-Undang Hukum Acara Pidana :

5) Pasal 56 (1) tentang : Dalam hal tersangka atau terdakwa disangka atau didakwa melakukan tindak pidana mati atau ancaman pidana lima belas tahun atau lebih atau bagi mereka yang tidak mampu yang diancam dengan pidana lima tahun atau lebih yang tidak mempunyai penasehat hukum sendiri, pejabat yang bersangkutan pada semua tingkat pemeriksaan dalam proses peradilan wajib menunjuk penasehat hukum bagi mereka ;

6) Pasal 56 (2) tentang : Setiap penasehat hukum yang ditunjuk untuk bertindak sebagaimana dimaksud dalam ayat (1), memberikan bantuannya dengan cuma-cuma.

7) Kitab Undang-Undang Hukum Acara Perdata (HIR/RBG) Pasal 237 HIR/273 RBG tentang : Barangsiapa yang hendak berperkara baik sebagai penggugat maupun sebagai tergugat, tetapi tidak mampu menanggung biayanya, dapat memperoleh izin untuk berperkara dengan cuma-cuma.

8) Instruksi Menteri Kehakiman RI No. M 01-UM.08.10 Tahun 1996, tentang Petunjuk Pelaksanaan Program Bantuan Hukum Bagi Masyarakat Yang Kurang Mampu Melalui Lembaga Bantuan Hukum.

9) Instruksi Menteri Kehakiman RI No. M 03-UM.06.02 Tahun 1999, tentang Petunjuk Pelaksanaan Program Bantuan Hukum Bagi Masyarakat Yang Kurang Mampu Melalui Pengadilan Negeri dan Pengadilan Tata Usaha Negara.

10) Surat Edaran Direktur Jenderal Badan Peradilan Umum dan Peradilan Tata Usaha Negara No. D.Um.08.10.10 tanggal 12 Mei 1998 tentang JUKLAK Pelaksanaan Bantuan Hukum Bagi Golongan Masyarakat Yang Kurang Mampu Melalui LBH.

Dana bantuan hukum tidak diberikan langsung melainkan diberi dalam bentuk imbalan jasa kepada Advokat yang sudah menyelesaikan kasus/perkara dari masyarakat yang bersangkutan. 
Dalam Undang-Undang Nomor 18 Tahun 2003 tentang Advokat, disebutkan bahwa kewajiban Advokat yaitu:

1) Dalam menjalankan tugas profesinya dilarang membedakan perlakuan terhadap Klien berdasarkan jenis kelamin, agama, politik, keturunan, ras, atau latar belakang sosial dan budaya.

2) Wajib merahasiakan segala sesuatu yang diketahui atau diperoleh dari kliennya karena hubungan profesinya, kecuali ditentukan lain oleh undang-undang.

3) Wajib memberikan bantuan hukum secara cuma-cuma kepada pencari keadilan yang tidak mampu.

4) Menjaga martabat dan kehormatan profesi Advokat.

5) Wajib tunduk dan mematuhi kode etik profesi Advokat dan ketentuan tentang Dewan Kehormatan Organisasi Advokat.

Adapun tugas dan tanggung jawab yang diemban advokat dan harus diperhatikan dalam menangani suatu perkara adalah sebagai berikut (Arto, 2001:133-134) :

1) Menjunjung tinggi kode etik profesinya;

2) Membimbing dan melindungi kliennya dari petaka duniawi dan ukhrawi agar dapat menemukan kebenaran dan keadilan yang memuaskan semua pihak, sesuai dengan nilai-nilai hukum, moral dan agama;

3) Membantu terciptanya proses peradilan yang sederhana, cepat dan biaya ringan, serta tercapainya penyelesaian perkara secara final;

4) Menghormati lembaga peradilan dan proses peradilan sesuai dengan norma hukum, agama, dan moral;

5) Melindungi kliennya dari kedzaliman pihak lain dan melindunginya pula dari berbuat dzalim kepada pihak lain;

6) Memegang teguh amanah yang diberikan kliennya dengan penuh tanggungjawab baik terhadap kliennya, diri sendiri, hukum dan moral, maupun terhadap Tuhan Yang Maha Esa;

7) Memberikan laporan dan penjelasan secara periodik kepada kliennya mengenai tugas yang dipercayakan padanya;

8) Menghindarkan diri dari berbagai bentuk pemerasan terselubung terhadap kliennya;

9) Bersikap simpatik dan turut merasakan apa yang diderita oleh kliennya bahkan mengutamakan kepentingan kliennya daripada kepentingan pribadinya;

10) Antara kuasa hukum atau advokat dengan kliennya haruslah terjalin hubungan saling percaya dan dapat dipercaya sehingga tidak saling merugikan dan dirugikan;

11) Melaksanakan tugas profesi sebagai pemberi jasa hukum bertindak jujur, adil, dan bertanggung jawab berdasarkan hukum dan keadilan; 
12) Advokat juga berkewajiban memberikan bantuan hukum secara cuma-cuma bagi klien yang tidak mampu, hal ini sesuai dengan Putusan Mahkamah Agung No. 5/KMA/1972 tentang golongan yang wajib memberikan bantuan hukum.

Advokat memiliki prinsip kerja yang kemudian disebut dan direduksi menjadi Kode Etik Profesi Advokat. Kode etik tersebut kemudian dijadikan dasar pijakan seorang advokat dalam menjalankan aktivitasnya sebagai penasihat hukum, kuasa hukum maupun penegak hukum sesuai dengan yang disebutkan dalam Pasal 26 Undang-Undang Nomor 18 Tahun 2003 tentang Advokat bahwa (Supriadi, 2006:87):

"Untuk menjaga martabat dan kehormatan profesi advokat disusun kode etik profesi advokat dan organisasi advokat. Maka advokat wajib tunduk dan mematuhi kode etik profesi advokat dan ketentuan tentang Dewan Kehormatan Organisasi Advokat".

Adapun kode etik advokat sebagai wujud kepribadian dalam menjalankan profesinya sebagai pemberi jasa layanan hukum yaitu (Supriadi, 2006:87) :

1) Advokat dapat menolak untuk memberi nasihat dan bantuan hukum kepada setiap orang yang memerlukan jasa hukum dan/atau bantuan hukum dikarenakan tidak sesuai dengan keahliannya dan bertentangan dengan hati nuraninya;

2) Dalam melakukan tugasnya tidak bertujuan untuk memperoleh materi saja tapi lebih mengutamakan tegaknya hukum, kebenaran dan keadilan;

3) Dalam menjalankan praktek profesinya harus bebas, mandiri dan tidak dipengaruhi oleh siapapun, dan wajib memperjuangkan hak asasi manusia;

4) Bersedia memberikan bantuan hukum pada siapa saja yang memerlukan tanpa memandang agama, ras, suku, keturunan, maupun keyakinan politiknya;

5) Advokat tidak dibenarkan melakukan pekerjaan lain yang dapat merugikan kebebasan, derajat, dan martabatnya;

6) Senantiasa menjunjung tingggi profesi advokat sebagai profesi terhormat;

7) Apabila advokat diangkat menjadi pejabat negara maka tidak dibenarkan membuka praktek sebagai advokat.

Dalam Kode Etik Profesi Advokat, selain ada kode etik kepribadian advokat juga terdapat kode etik terkait hubungannya dengan klien (Pasal 4 Kode Etik Advokat), yaitu:

1) Advokat harus mengutamakan penyelesaian dengan jalan damai; 
2) Tidak dibenarkan memberikan keterangan yang menyesatkan klien dan tidak dibenarkan pula untuk menjamin bahwa ia akan memenangkan perkara;

3) Dalam menentukan honorarium advokat harus mendasarkan pada kemampuan klien dan tidak dibenarkan membebani klien dengan biaya yang tidak perlu;

4) Wajib menjaga rahasia klien bahkan sampai berakhirnya hubungan antara advokat dan klien tersebut;

5) Mementingkan kepentingan klien diatas kepentingan pribadinya.

Adapun kode etik yang berhubungan dengan cara kerja advokat khususnya dalam menangani perkara seorang advokat harus memegang rahasia yang berkaitan dengan rahasia jabatan yang melekat pada dirinya (Ishaq, 2012:53-56).

Advokat dalam membela kliennya harus memegang teguh prinsip Equality before the Law yakni jaminan kesederajatan di hadapan hukum dan prinsip Presumption of innocene (praduga tak bersalah) yakni menganggap kliennya benar berdasarkan data dan informasi yang diberikan padanya. Prinsip tersebut dilaksanakan agar di dalam pembelaannya, seorang Advokat berani menjalankan profesi dan fungsinya dengan efektif.

Bagi masyarakat tidak mampu yang yang menghadapi perkara di pengadilan, dalam rangka membela dan melindungi hak-hak hukumnya dapat meminta keterangan (informasi) dari instansi-instansi setempat, seperti: Pengadilan Negeri atau pengadilan Tinggi, kejaksaan Negeri atau Kejaksaan Tinggi, dan Lembaga bantuan Hukum, dengan menyiapkan Surat Keterangan Tidak Mampu dari Kepala Desa/Lurah setempat; atau Surat Pernyataan Tidak Mampu dari Pemohon dan dibenarkan oleh Pengadilan Negeri setempat; atau Surat Pernyataan Tidak Mampu dari Pemohon dan dibenarkan oleh Lembaga Bantuan Hukum setempat (Anonim, 2016).

\section{B. Sudut Pandang Hak Asasi Manusia Menilai Bantuan Hukum yang Diberikan oleh Advokat}

Hak-hak ini diatur dalam Undang-Undang Dasar 1945 Pasal 28 D ayat (1) yang berbunyi, "Setiap orang berhak atas pengakuan, jaminan, perlindungan, dan kepastian hukum yang adil serta perlakuan yang sama di hadapan hukum".

Implementasi Pasal 28D UUD 1945 ayat 1 dapat dijalankan dengan menegakkan supremasi hukum bagi tiap masyarakat. Hukum berfungsi mengatur segala hal agar dapat berjalan tertib dan sesuai dengan aturan. Namun, apa yang terjadi adalah hukum di negara ini seperti dua sisi mata pisau. Tumpul bagi kalangan atas dan tajam bagi kalangan bawah.

Bagi kalangan atas, orang-orang yang memiliki uang, mereka seperti kebal akan hukum. Kasus korupsi yang marak terjadi di Indonesia dilakukan oleh pejabat-pejabat negara, banyak menimbulkan kerugian bagi negara dan masyarakat 
banyak, namun hukuman yang diberikan tak seberapa. Sedangkan para kalangan bawah yang melakukan kejahatan kecil, dapat dipenjara.

Di tambah bagi mereka yang merupakan kalangan tidak mampu dan buta hukum, yang menghadapi kasus di pengadilan, jika tidak memperoleh bantuan hukum, maka besar kemungkinan mereka tidak akan mendapat keadilan dalam persidangan. Tugas seorang advokat sebagai pemberi bantuan hukum, bukan berarti seorang advokat harus membela kliennya jika memang terbukti bersalah. Akan tetapi, mereka menjamin dan mendampingi agar kliennya mendapat keadilan di dalam dan di luar persidangan.

Hak untuk memperoleh jaminan di dalam hukum telah diatur di dalam banyak instrumen hukum selain di dalam UUD 1945. Diantaranya adalah, Undang-Undang Nomor 39 Tahun 1999 tentang Hak Asasi Manusia, Bab II, Pasal 3 ayat (2), yang berbunyi, "Setiap orang berhak atas pengakuan, jaminan, perlindungan dan perlakuan hukum yang adil serta mendapat kepastian hukum dalam semangat di depan hukum". Kemudian diatur dalam Pasal 5 ayat (1) dan (2).

Universal Declaration of Human Rights, Article 10 (Pasal 10): "Setiap orang, dalam persamaan yang penuh, berhak atas peradilan yang adil dan terbuka oleh pengadilan yang bebas dan tidak memihak, dalam menetapkan hak dan kewajibankewajibannya serta dalam setiap tuntutan pidana yang dijatuhkan kepadanya."

Keputusan Presiden Republik Indonesia Nomor 50 Tahun 1993 Tentang Komisi Nasional Hak Asasi Manusia, Pada Bab II, Pasal 5, huruf c menyatakan, "Memantau dan menyelidiki pelaksanaan hak asasi manusia serta memberikan pendapat, pertimbangan dan saran kepada badan pemerintahan Negara mengenai pelaksanaan hak asasi manusia" yang dalam konteks kali ini mengarah pada pemberian bantuan hukum kepada masyarakat kurang mampu/ miskin.

Sebelumnya, Pasal 4 mengatur mengenai tujuan dari Komisi Nasional, yaitu:

a. Membantu pengembangan kondisi yang kondusif bagi pelaksanaan hak asasi manusia sesuai dengan Pancasila, Undang-Undang Dasar 1945, dan Piagam Perserikatan Bangsa-Bangsa serta Deklarasi Universal Hak Asasi Manusia;

b. meningkatkan perlindungan hak asasi manusia guna mendukung terwujudnya tujuan pembangunan nasional yaitu pembangunan Manusia Indonesia seutuhnya dan pembangunan masyarakat Indonesia seluruhnya.

Dalam sejarah kehidupan bangsa Indonesia, upaya penegakan dan perlindungan HAM telah mengalami pasang surut. Pada suatu masa upaya tersebut berhasil diperjuangkan, tetapi pada masa lain dikalahkan oleh kepentingan kekuasaan. Disadari bahwa kehidupan berbangsa dan bernegara yang tidak mengindahkan penghormatan, penegakan dan perlindungan HAM akan selalu menimbulkan ketidakadilan bagi masyarakat luas dan tidak memberikan landasan yang sehat bagi pembangunan ekonomi, politik, sosial dan budaya untuk jangka panjang. Sejumlah negara bahkan telah melangkah jauh dalam mencapai standar 
internasional HAM, yang diantaranya dilakukan dengan mendirikan Komisi Nasional untuk HAM (Yuliarso dkk, Jurnal Ilmu Politik, Vol 2, No 3, Maret 2005: 295).

Perubahan kedua Undang-Undang Dasar 1945 menyempurnakan komitmen Indonesia terhadap upaya pemajuan dan perlindungan HAM dengan mengintegrasikan ketentuan-kelentuan penting dari instrumen-instrumen internasional mengenai HAM, sebagaimana tercantum dalam BAB XA tentang Hak Asasi Manusia. Perubahan tersebut dipertahankan sampai sekarang.

Guna mengamanatkan pemajuan dan perlindungan hak asasi manusia dalam kehidupan bermasyarakat, berbangsa, dan bernegara serta komitmen bangsa Indonesia sebagai bagian dari masyarakat internasional untuk memajukan dan melindungi HAM, Indonesia mengesahkan instrumen-instrumen internasional utama mengenai HAM, khususnya International Covenant on Economic, Social and Cultural Rights (Kovenan Internasional tentang Hak-hak Ekonomi, Sosial dan Budaya) serta International Covenant on Civil and Political Rights (Kovenan Internasional tentang Hak-hak Sipil dan Politik).

Berdasar Ketetapan Majelis Permusyawaratan Rakyat Republik Indonesia Nomor XVII/MPR/1998 tentang Hak Asasi Manusia, menjelaskan bahwa substansi hak asasi manusia meliputi; hak untuk hidup; hak berkeluarga dan melanjutkan keturunan; hak mengembangkan diri; hak keadilan; hak kemerdekaan; hak berkomunikasi; hak keamanan; dan bak kesejahteraan. Pada Bagian II, Bab IV tentang Hak Keadilan dalam Piagam Hak Asasi Manusia, diatur mengenai hak individu di dalam hukum yaitu pada Pasal 7 dan Pasal 8.

Pasal 7 berbunyi, "Setiap orang, berhak atas pengakuan, jaminan, perlindungan, dan perlakuan hukum yang adil". Dilanjut dengan Pasal 8, "Setiap orang berhak mendapat kepastian hukum dan perlakuan yang sama di hadapan hukum".

Selanjutnya pada Pasal 37 menyebutkan bahwa "Hak untuk hidup, hak untuk tidak disiksa, hak kemerdekaan pikiran dan hati nurani, hak beragama, hak untuk tidak diperbudak, hak untuk diakui sebagai pribadi di hadapan hukum, dan hak untuk tidak dituntut atas dasar hukum yang berlaku surut adalah hak asasi manusia yang tidak dapat dikurangi dalam keadaan apapun (non-derogable)." Nonderogable, di sini merupakan hak yang dalam kondisi apapun tidak dapat dirampas secara paksa oleh orang lain.

Dan bagi kelompok masyarakat yang rentan, seperti anak-anak dan fakir miskin, berhak mendapatkan perlindungan lebih terhadap hak asasinya. Perlindungan, pemajuan, penegakan, dan pemenuhan hak asasi manusia terutama menjadi tanggung jawab Pemerintah.

Ron Dudai berpendapat "One key factor in re-energizing human rights is to reconnect human rights with social movements struggles on the ground. Human rights-as slogans, values, methods, laws, and institutional machinery-are most effectively deployed not in the abstract but in conjunction with and in support of specific campaigns, and their role 
and function should be to assist such concrete struggles." (Salah satu faktor kunci dalam memberi energi kembali hak asasi manusia adalah untuk menghubungkan kembali hak asasi manusia dengan gerakan sosial yang sedang berjuang di lapangan. Hak asasi manusia-sebagai slogan, nilai, metode, undang-undang, dan mesin kelembagaan-paling efektif digunakan bukan secara abstrak namun bersamaan dengan dan mendukung kampanye tertentu, dan peran dan fungsinya harus membantu perjuangan konkret semacam itu). (Dudai, Jurnal of Human Rights Practice, 9, 2017:18)

Menurut data Komnasham, justru pemerintah daerah menjadi salah satu sumber ancaman bagi penegakan HAM di Indonesia. Padahal, sejatinya, sebagai wakil pemerintah pusat di daerah, pemerintah daerah seyogyanya berperan aktif dalam penghormatan, pemenuhan, dan perlindungan HAM di Indonesia. (Mulyana, Jurnal HAM Komisis Nasional Hak Asasi Manusia, 8, 2016: 151)

Penegakan hukum pada prinsipnya harus memberikan manfaat atau berdaya guna bagi masyarakat. Disamping itu masyarakat juga mengharapkan adanya penegakan hukum dalam rangka mencapai suatu keadilan. Dengan demikian tidak dapat dipungkiri, bahwa apa yang dianggap berguna belum tentu adil, juga sebaliknya apa yang dirasakan adil, belum tentu berguna bagi masyarakat. Penegakan hukum, dimanapun di belahan bumi ini tidak bisa terlepas dari hak asasi serta penegakan hukum yang dibarengi dengan adanya unsur kekerasan, walaupun cara dan pelaksanaan kekerasan tersebut berlainan, sorotan yang sarkartis dari masyarakat tehadap penegakan hukum terutama ditujukan kepada aparat penegak hukum paling depan yang berhubungan langsung dengan masyarakat, seperti Polisi, aparat ketertiban umum dan petugas-petugas Kamtibmas. (Rusydi, Pandecta, Vol 9 No 2, 2014: 227)

Berdasarkan Pasal 34 ayat (1) UUD 1945 ditegaskan bahwa "Fakir miskin dan anak-anak yang terlantar dipelihara oleh negara". Berdasarkan ketentuan Pasal 34 ayat (1) UUD 1945 tersebut negara mengakui hak ekonomi, sosial, budaya, sipil dan politik dari fakir miskin. Atas dasar pertimbangan tersebut, fakir miskin memiliki hak untuk diwakili dan dibela oleh advokat baik di dalam maupun di luar pengadilan sama seperti orang mampu yang mendapatkan jasa hukum dari advokat. Penegasan sebagaimana diambil dari Pasal 34 ayat (1) UUD 1945 memberikan implikasi bahwa bantuan hukum bagi fakir miskin pun merupakan tugas dan tanggung jawab negara dan merupakan hak konstitusional.

Di negara berkembang seperti Indonesia, adanya organisasi bantuan hukum merupakan hal yang penting, yaitu untuk membantu fakir miskin dalam menghadapi masalah-masalah hukum karena organisasi bantuan hukum ini dapat mengurangi kemungkinan fakir miskin tidak memperoleh bantuan hukum untuk membela kepentingan hukumnya baik di dalam maupun di luar pengadilan. Organisasi bantuan hukum dapat membantu fakir miskin untuk dapat memperoleh pengetahuan tentang hukum, hak asasi manusia, hak sipil dan politik, hak sosial, 
hak budaya, dan hak ekonomi. International Covenant on Civil and Political Rights (ICCPR) diratifikasi Indonesia dengan Undang-Undang Nomor 12 Tahun 2005 dan International Covenant on Economic, Social and Cultural Rights (ICESCR) diratifikasi dengan Undang-Undang Nomor 1 Tahun 2005 untuk memperkuat kewajiban pemerintah/negara untuk membantu hak fakir miskin baik dalam bidang politik, sosial dan ekonomi, serta bantuan hukum.

Hak atas bantuan hukum bagi masyarakat miskin yang berhadapan dengan hukum diatur untuk memastikan pemenuhan jaminan perlindungan kepastian hukum yang adil (fair trial) dan persamaan dimuka hukum (equality before the law). Prinsip tersebut terdapat dalam International Convenant on Civil and Political Rights (ICCPR) yang telah diakomodir dalam konstitusi dan telah diratifikasi melalui Undang-Undang Nomor 12 Tahun 2005.

Prinsip didalam ICCPR tersebut dapat diklasifikasikan dalam tiga kategori yaitu Prinsip Dasar Fair Trial, Jaminan Prosedur Minimum, dan Ketentuan Lain yang kemudian diadopsi dalam beberapa ketentuan hukum seperti UndangUndang Nomor 8 Tahun 1981 tentang Kitab Undang-Undang Hukum Acara Pidana (KUHAP), Undang-Undang Nomor 9 Tahun 1999 tentang HAM, UndangUndang Nomor 3 Tahun 1997 tentang Pengadilan Anak dan Undang-Undang Nomor 23 Tahun 2003 tentang Perlindungan Anak, Undang-Undang Nomor 13 Tahun 2006 Perlindungan Saksi dan Korban, Undang-Undang Nomor 48 Tahun 2009 tentang Kekuasaan Kehakiman.

Jaminan hak atas bantuan hukum diperkuat melalui Undang-Undang Nomor 18 Tahun 2003 tentang Advokat sebagai regulasi pelaksana pemberian bantuan hukum yang menempatkan advokat sebagai subyek utama pemberi bantuan hukum.

Namun hambatan perundang-undangan yang dialami selama ini adalah tidak adanya jaminan untuk memperoleh pembelaan baik bagi orang mampu maupun fakir miskin baik di dalam UUD 1945 maupun di dalam KUHAP. Semenjak Undang-Undang Nomor 18 Tahun 2003 disahkan, pemberian bantuan hukum bukan lagi menjadi hal yang menyangkut etika ataupun kesukarelaan tiap advokat, namun merupakan sesuatu yang diwajibkan oleh undang-undang. Ketentuan Pasal 22 ayat (1) Undang-Undang Nomor 18 Tahun 2003 dengan tegas menyatakan bahwa, "Advokat wajib memberikan bantuan hukum secara cuma-cuma kepada pencari keadilan yang tidak mampu".

Agar bantuan hukum yang diberikan bermanfaat bagi seluruh masyarakat, maka perlu dalam pelaksanaannya dilakukan secara merata dengan penyaluran melalui berbagai institusi penegakan hukum yang ada seperti pengadilan, kejaksaan, organisasi advokat, maupun organisasi-organisasi masyarakat yang bergerak dibidang bantuan hukum. Pelaksanaan bantuan hukum kepada masyarakat tidak hanya sebatas untuk memenuhi kebutuhan masyarakat akan pendampingan advokat dalam setiap proses hukum melainkan lebih dari hal 
tersebut yaitu adalah bagaimana menjadikan masyarakat untuk mengerti hukum dan dapat mengkritisi produk hukum yang ada.

Dengan disahkannya Undang-Undang tentang Bantuan Hukum (UndangUndang Nomor 16 Tahun 2011 tentang Bantuan Hukum) saat sidang paripurna pada 4 Oktober 2011, diharapkan akan meringankan beban kepada seluruh warga negara tidak mampu dalam segi ekonomi yang tersandung masalah hukum bisa dibantu oleh Pemerintah. Bantuan hukum untuk membantu masyarakat yang tidak mampu, bisa diambilkan dari Lembaga Bantuan Hukum (LBH) atau yang lainnya. (Priyambodo, 2011)

Undang-Undang Nomor 8 Tahun 1981 tentang Hukum Acara Pidana, mengatur mengenai hak dari tersangka atau terdakwa dalam mengahadapi persidangan, yang diberi hak untuk menggunakan jasa bantuan hukum (pengacara/advokat/penasihat hukum) dan memilih sendiri pengacara/advokat/penasihat hukumnya.

Pasal 54, berbunyi: "Guna kepentingan pembelaan, tersangka atau terdakwa berhak mendapat bantuan hukum dari seorang atau lebih penasihat hukum selama dalam waktu dan pada setiap tingkat pemeriksaan, menurut tata cara yang ditentukan dalam undang-undang ini". Kemudian pada Pasal 55, mengatakan bahwa tersangka atau terdakwa berhak memilih sendiri penasihat hukumnya. Memberikan bantuan hukum kepada pencari keadilan miskin adalah kewajiban setiap advokat. Pemberian bantuan hukum secara cuma-cuma ini disebut dengan istilah "probono publico". Bantuan hukum dalam konsep probono meliputi empat elemen, yaitu: 1) Meliputi seluruh kerja-kerja di wilayah hukum; 2) Sukarela ; 3) Cuma-Cuma; dan 4) Untuk Masyarakat yang kurang terwakili dan rentan. Kewajiban ini sebagai sebuah tanggung jawab moral advokat sebagai profesi terhormat (officium nobbile).

Kewajiban bantuan hukum cuma-cuma (probono publico) ini diatur dalam Undang-Undang Nomor 18 Tahun 2003 tentang Advokat, Peraturan Pemerintah Nomor 83 Tahun 2008 tentang Persyaratan dan Tata Cara Pemberian Bantuan Hukum Secara cuma-cuma dan Peraturan Peradi Nomor 1 tahun 2010 tentang Petunjuk Pelaksanaan Pemberian Bantuan Hukum Secara Cuma-Cuma serta Kode Etik Advokat.

Pada sekarang ini sulit untuk menemui advokat yang memberi bantuan hukum secara probono. Banyak faktor yang menyebabkan pengacara enggan untuk langsung memberikan bantuan hukum secara cuma-cuma. Ada yang merasa dulu sudah pernah melakukan. Ada juga yang menganggap lebih baik memberikan dananya ke LBH yang fokus pada upaya probono. Tidak adanya insentif dari pemerintah juga dinilai turut berpengaruh. Misalnya hanya firma hukum yang anggotanya pernah memberikan bantuan hukum probono yang boleh ikut tendertender pemerintah. Selain itu, ketiadaan upaya paksa dari organisasi menyebabkan kewajiban memberikan bantuan hukum cuma-cuma tidak bisa ditegakkan. 
Untuk mengatasi persoalan itu, ada beberapa opsi yang bisa dilakukan. Misalnya, memberikan bantuan hukum terhadap orang miskin sebagai salah satu syarat untuk mendapatkan lisensi advokat. Bisa juga opsi lain, kantor-kantor pengacara besar membentuk divisi khusus probono atau divisi public services, atau opsi-opsi lainnya.

Dalam konsultasi publik RPP Bantuan Hukum 24 April 2012, Ketua Umum DPN PERADI, Otto Hasibuan, menyinggung pentingnya kualitas pemberian bantuan hukum kepada warga miskin. Kualitas layanan yang diberikan juga harus dipikirkan. PERADI setuju pada kewajiban advokat memberikan bantuan hukum secara probono. Hal yang menjadi concern pengurus adalah pengaturan tentang biaya faktual dan biaya siding karena tidak semua advokat mampu.

Jika demikian maka akan terjadi pelanggaran terhadap hak-hak asasi manusia di dalam hukum untuk bisa mendapatkan keadilan dalam berhukum, apalagi bagi masyarakat yang tidak mampu dan buta hukum.

\section{KESIMPULAN}

Dari pembahasan di atas, dapat disimpulkan bahwa menurut Pasal 1 angka 1 Bab I Undang-Undang Nomor 16 Tahun 2011 tentang Bantuan Hukum, menyebutkan: "Bantuan Hukum adalah jasa hukum yang diberikan oleh Pemberi Bantuan Hukum secara cuma-cuma kepada Penerima Bantuan Hukum". Bantuan hukum dapat dilakukan oleh Advokat, Paralegal, Dosen Fakultas Hukum, dan Mahasiswa Fakultas Hukum. Namun yang utama yaitu oleh Advokat, sebagaimana telah diatur di dalam Undang-Undang Nomor 18 Tahun 2003 tentang Advokat. Sasaran penerima bantuan hukum yaitu fakir miskin atau rakyat yang tidak mampu, di mana mereka akan mendapat bantuan hukum secara cuma-cuma dalam berperkara.

Kemudian jika ditinjau dari perspektif HAM, bantuan hukum merupakan salah satu hak asasi yang wajib diterima olehnya dalam berhukum, agar mendapatkan keadilan. Seperti tertuang di dalam Undang-Undang Dasar 1945, yang mengatur mengenai hak asasi manusia, yang salah satunya yaitu hak untuk mendapat jaminan dan keadilan di dalam hukum. Jadi, bagi warga negara Indonesia, yang merupakan kalangan tidak mampu tetap berhak mendapatkan bantuan hukum dalam berperkara di persidangan. 


\section{DAFTAR PUSTAKA}

\section{Peraturan Perundang-Undangan}

Undang-Undang Dasar 1945

Undang-Undang Nomor 39 Tahun 1999 tentang Hak Asasi Manusia

Undang-Undang Nomor 16 Tahun 2011 tentang Bantuan Hukum

Undang-Undang Nomor 18 Tahun 2003 tentang Advokat

Undang-Undang Nomor 11 Tahun 2005 tentang Pengesahan International Covenant On Economic, Social And Cultural Rights (Kovenan Internasional Tentang Hak-Hak Ekonomi, Sosial Dan Budaya)

Universal Declaration of Human Rights (UDHR)

Keputusan Presiden Republik Indonesia Nomor 50 Tahun 1993 tentang Komisi Nasional Hak Asasi Manusia Presiden Republik Indonesia

Buku

Abdurrahman. 1980. Aneka Masalah Dalam Praktek Penegakan Hukum di Indonesia. Bandung: Penerbit Alumni.

Arto, Mukti. 2001. Mencari Keadilan (Kritik Solusi terhadap Praktik Peradilan Perdata di Indonesia), Yogyakarta: Pustaka Pelajar.

Supriadi. 2006. Etika dan Tanggung Jawab Profesi Hukum di Indonesia. Jakarta: Sinar Grafika.

Ishaq. 2012. Pendidikan Keadvokatan. Jakarta: Sinar Grafika.

Jurnal

Ron Dudai. "Human Rights in the Populist Era: Mourn then (Re)Organize". Journal of Human Rights Practice, 9, (2017): hlm 16-21.

Yuliarso, Kurniawan Kunto dan Nunung Prajarto. "Hak Asasi Manusia (HAM) di Indonesia: Menuju Democratic Governances". Jurnal Ilmu Politik Volume 8, Nomor 3, Maret (2005): hlm 291-308.

Asep Mulyana. "HAM dan Pemerintah Daerah: Ikhtiar Membumikan HAM di Level Lokal". Jurnal HAM Komisi Nasional Hak Asasi Manusia Volume XIII (2016): hlm 1-225

Yudistira Rusydi. "Wewenang dan Hambatan Penyidik Pegawai Negeri Sipil Satuan Polisi Pamong Praja dalam Pelaksanaan Upaya Paksa terhadap Pelanggaran Kasus Asusila". Pandecta Volume 9. Nomor 2. Januari (2014): hlm 226-238.

\section{Sumber Online}

Anonim. "Prosedur Bantuan Hukum". http://www.pn-trenggalek.go.id/prosedurbantuan-hukum/layanan-hukum/layanan-hukum-masyarakat-kurangmampu/prosedur-bantuan-hukum diakses pada Sabtu, 14 Oktober 2017.

Priyambodo RH, "UU bantuan hukum pada 2013 sudah berlaku". http://www.antaranews.com/berita/278857/uu-bantuan-hukum-pada2013-sudah-berlaku diakses pada Sabtu, 14 Oktober 2017 